Paola Davoli

\title{
Papyri and Ostraca as Archaeological Objects: The Importance of Context
}

\section{Introduction}

When in 1996 I started recording the physical properties of the ostraca found in the excavation at Bakchias/Kom Umm el-Atl in the Fayum as field archaeological director of the Joint Archaeological Mission of Bologna and Lecce Universities, I strongly believed that ostraca and papyri were archaeological objects and that they must be documented as such. ${ }^{1}$ While these objects are important because of the texts written on them, they also have material properties, which should not be ignored since they are an integral part of the object and of its production process. An ostracon consists of a pottery support, a fragment of a vessel, on which someone wrote a text: in modern archaeological perspective, every object is part of production and consumption processes that are strictly linked with manufacturing technology and with personal, social, and cultural uses. This kind of cultural contextualization of objects allows us to study them as an integral part of life of the society that produced and used them, and not only as single items, pieces of art or texts.

In the process of recording ostraca I became fascinated by a very basic question to which I did not have an answer: was the pottery fragment simply a piece of garbage found and used by chance by the scribe or, on the contrary, was it a purposeful choice? At that time, I had only a vague vision of the potential advantage of recording information about the material support of ostraca and would not imagine that it would become an important topic in papyrology, as Roger Bagnall pointed out in a recent article. ${ }^{2}$ I continued documenting ostraca supports also in my other field engagements with the help of ceramologists and registrars, in the hope to collect, sooner or later, a data-set that would be large and representative enough for a statistical analysis to try to answer my question. And the time and the persons did arrive, with Clementina Caputo's PhD research and now with the project directed by Julia Lougovaya. ${ }^{3}$ The recording of the ostraca supports went far beyond my first experience and has produced impressive results reflected in recent publications and in several contributions in this volume. ${ }^{4}$

\footnotetext{
1 The documentation of ostraca supports was still not common in the 1990s: see Caputo 2018, 677701; Caputo 2019. The data concerning the supports of Bakchias ostraca are included in M. Capasso's annual reports published in several volumes edited by Pernigotti/Capasso 1996-1999, 2000-2003.

2 Cf. Bagnall 2016, 79-87.

3 Caputo 2014, "Per una nuova interpretazione culturale della ceramica vascolare nell'Egitto GrecoRomano," unpublished PhD dissertation defended at the University of Salento in a cotutelle program with the University of Poitiers.

4 Caputo/Cowey 2018, 62-75.

¿ Open Access. () 2020 Paola Davoli, published by De Gruyter (c) BY-NC-ND This work is licensed under the Creative Commons Attribution-NonCommercial-NoDerivatives 4.0 License. 
As archaeological finds ostraca (and papyri) need to be recorded as objects found in specific archaeological contexts, the interpretation of which is crucial for a correct understanding of the use of the items. In this paper, I will focus my attention on the importance of the correct documentation and interpretation of the contexts $v s$ ostraca.

\section{Theoretical Approach}

My field approach to ostraca and papyri is mainly archaeological. They are archaeological objects just as all the other potsherds and objects found during the excavation and they must be processed, recorded, and studied as such. However, they also bear additional information by the virtue of being inscribed with texts which can tell us more about people involved, or dates and events concerned, or some economic parameters. ${ }^{5}$ This information can clarify the context of the excavation, and give it a more precise sense $^{6}$ and, vice versa, the archaeological context can add valuable information to the texts. This, however, should not be viewed as an easy equation because any archaeological context is the result of a long and complex formation process.

In the last decades there has been a growing interest in combining textual and archaeological data in different geographical areas and historical periods, and consequently discussions of the theoretical approach have been on the rise, too. ${ }^{7}$ The "archaeology of texts" or "texts in context" have become familiar topics also in the field of papyrology, where they entail studying papyri in their archaeological find contexts, when these are documented. ${ }^{8}$ So far, it has been rather papyrologists than archaeologists (or papyrologists in collaboration with archaeologists) who practice this kind of approaches in the analysis of the materials from excavations that are particularly interesting for the rich papyrological evidence in context, like those carried out between 1924 and 1934 by the University of Michigan at Karanis/Kom Aushim, or more recently by Monash University at Kellis/Ismant el-Kharab. ${ }^{9}$ Naturally, these

5 This is also true for all the objects with inscriptions.

6 The term "context" can have a variety of meanings, from material to cultural and historical, from local to global. Here "archaeological context" refers to physical entities, from the entire building with the stratigraphy found in it as a whole, to a single Stratigraphic Unit. For an overview of the use of this term in literature, see Carandini 2017; Gagos/Gates/Wilburn 2005, 171-173.

7 This trend can be considered as part of a wider scholarly debate about the necessity of integrating historical and archaeological data: see at least the first issue of Archaeology and Text: A Journal for the Integration of Material Culture with Written Documents in the Ancient Mediterranean and Near East 1 (2017). On a wide perspective: Moreland 2006, 135-151. See also Wilburn/Cook/Gates-Foster 2014, 157-160; Davoli 2001.

8 For a useful overview, see Gagos/Gates/Wilburn 2005, 171-188.

9 Minnen 1994, 227-251; Stephan/Verhoogt 2005, 189-201; Cuvigny 2009, 30-58. T. G. Wilfong has successfully re-contextualized Coptic ostraca from Medinet Habu House 34 and identified a family archive, but could not carry out a more precise study of the house and its content because of the very poor 
studies focus on the texts and the contexts tend to be described vaguely, with other items found there only listed and not studied in detail, especially in the cases when the documentation of earlier excavations is the base of the research. While these attempts show the importance of such an integrated approach, they also reveal the difficulties of interpreting archaeological data sets. As a result, two main views have prevailed, an optimistic and a pessimistic one. Holders of the first ${ }^{10}$ tend to assume that the presence of texts, and especially of a coherent cluster of them (like ancient archives) must have something to do with the place where they are found and with the people that produced or used those texts. Other objects found in the same context are considered and interpreted in the light of the texts and not by themselves, in their materiality and typology. ${ }^{11}$

The pessimistic ${ }^{12}$ view, on the contrary, holds that although texts may help a little in the interpretation of the archaeological context in which they were found, they cannot be used to date the other artefacts from the same context. In this kind of theoretical frame, a wide-scale approach to texts and contexts from the same settlement is the only possible attempt that can give a chance to achieve general or "ideal" results. ${ }^{13}$

Both positive and negative arguments adduced by scholars in particular studycases might be convincing, ${ }^{14}$ but the results are not fully satisfactory because texts bring into mute contexts very detailed data, like names of people and dates, which find no correspondence, and some time are, or seem to be, in contrast with the find place and the other items.

What should we think then about the feasibility of combining archaeological and textual data? Can we consider this opportunity as a real chance to enhance our

\footnotetext{
documentation from the 1929 excavations: Wilfong 1990, 169-181. Th. Landvatter's study of Karanis House B224 and its papyri reveals a theoretically correct archaeological approach in examining the problems of the interpretation of papyri found in archaeological contexts. However, it seems that the archaeological situation, and thus the reasons of the "mistake" made by the Michigan archaeologists in attributing the same bunch of papyri to two different levels, has not been completely understood. See Landvatter 2016, 1493-1518. On Kellis, see Nevett 2011, 15-31; Bowen 2015, with previous bibliography. 10 Minnen 1994; Stephan 2010, 92-131.

11 See for example Minnen 1994.

12 Husselman 1971, 9; Nevett 2011, 15-31.

13 For an example of reconstructing an "ideal type house" in Mesopotamia on the basis of archaeological, textual, and ethnographical sources, see Faivre 2015, 293-309. Visual reconstruction techniques can be employed to integrate archaeological and textual data in creating an ideal image of the past, cf. Pavel 2017, 67-94.

14 Nevett 2011 does not seem to take into account the fact that the buildings found are just the ruins of the original buildings and that, for example, roofs and upper stories are missing. The materials once stored above the ground floor ceiling may have disappeared due to the erosion or to human activities; alternatively, they may have fallen on the floors of the ground floor or collapsed into the filling of the rooms. In other words, objects found in the ruins of the ground floor rooms could have been stored originally on the upper stories and consequently they would not be necessarily associated with the people that once lived in the ground floor.
} 
knowledge of the past or is it, due to the practical constraints, simply wishful thinking? Generalization is always a mistake, particularly in archaeology, where an unpredictable number of actions, positive and negative, natural and anthropic, may have affected the artefacts and their contexts, both during and after their life span. While I share the general pessimism that comes from some of the attempts already made to combine textual and archaeological data, especially those from old excavations, I nevertheless believe that there is a possible, alternative way to use the data more consistently. The way to proceed must be from the archaeological study of the context, such as by the stratigraphic units, to the texts, and not the other way around, from the texts to the context.

From an archaeological perspective, the findspot of an object is not a sufficient reason to assign it to the people that lived in the context or building where it was found, even if it is in a primary deposition. A good example is the famous bunch of papyri reused as filling in a threshold in House C 5026 at Karanis: they are certainly in primary deposition, but this was not their primary use. ${ }^{15}$ Understanding and interpreting archaeological contexts is a very difficult task because it starts from the very moment of the excavation and continues during the study of all the data recovered and the documentation produced during the excavation. To be able to use and understand the detailed information from texts found in context, we must first of all distinguish between primary deposition and primary use of the objects and of the texts, while remembering that there may be more than one possible explanations for the formation of a context because the evidence is not necessarily all consistent.

As renowned archaeologists once stated, we have to keep in mind that "archaeologists do not discover the past as it was; they work on what becomes of what was."16 With this limitation in mind, it is therefore possible to investigate the past through the combination of what remains of it. In particular, the identification of the stratigraphy and the interpretation of its formation ${ }^{17}$ are essential for the following contextual study. In this perspective, the materials found in single layers/stratigraphic units will gain a meaning, which is not necessarily their primary use (although it may be), but is mainly related to the dynamics that led individual objects to share a common deposition or context with other objects. As an example, we can mention an assemblage of objects found on the floor of a laconicum, a part of the thermae building, excavated in Trimithis/Amheida (Fig. 1). There were several bowls, pigments and lumps of gypsum, iron nails and mud bricks, all materials not strictly related to the use of the thermae and not coherent with each other. Taken one by one, they can be defined and assigned a function, which may even fit-one way or another-the function of the room: the plaster may have been used to renovate the room, while the bowls may have served

15 Claytor 2014, 161-164.

16 Rathje/Shanks/Witmore 2013, 5.

17 Schiffer 1987. 


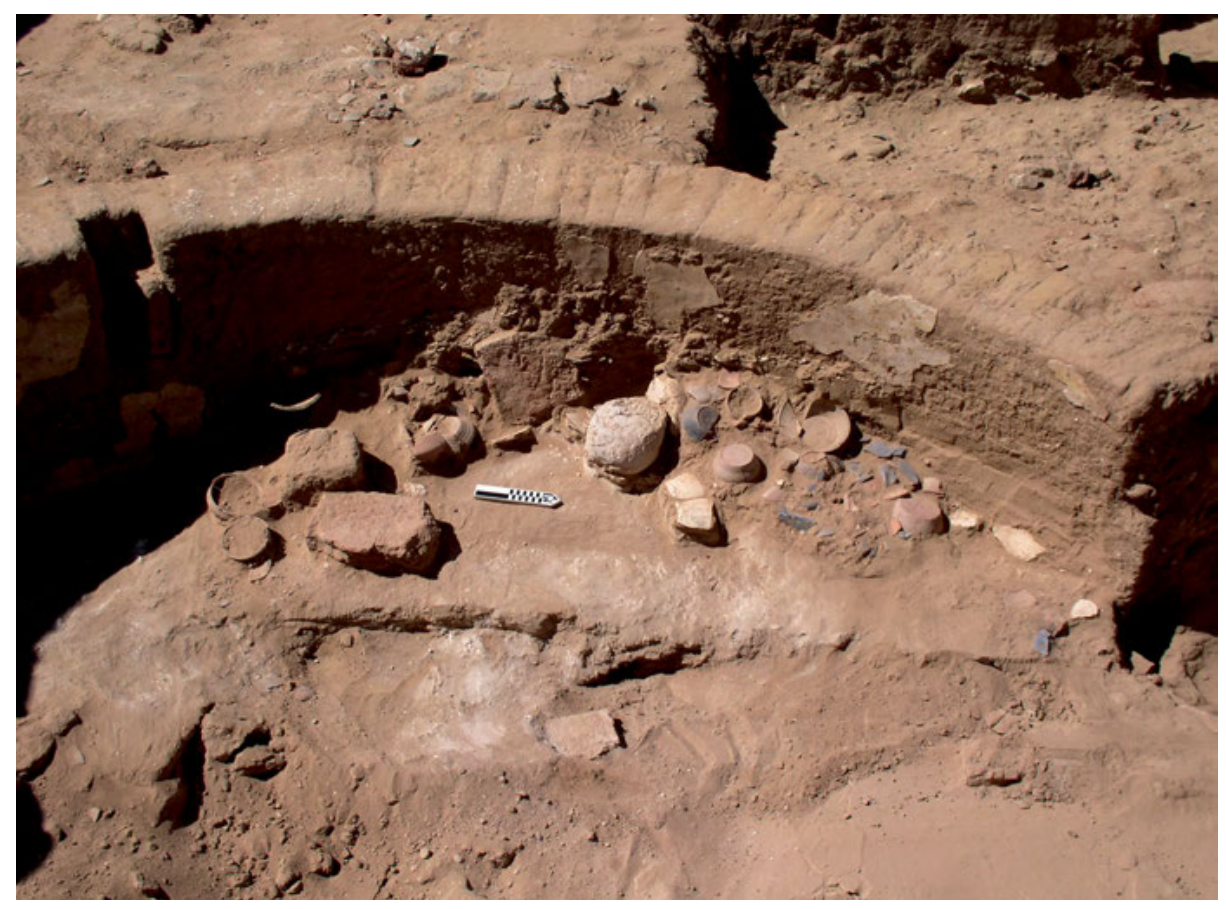

Fig. 1: Amheida area 2.1. Abandoned laconicum of a public bath of Roman period with waste on its floor.

for drinking water or to mix the colors during the renovation works. However, studied all together in their context they reveal a specific formation process of the deposit and a completely different meaning of simply being waste, objects thrown out in an abandoned and partly demolished room, the laconicum. It is therefore evident that in order to establish the relationship of an object, or of a text, with its find context, it is essential to understand the nature and the formation process of the archaeological deposit, and not just the place, in which it was found.${ }^{18}$ The correct evaluation of the nature of the stratigraphic unit is thus crucial for the interpretation of the texts and the objects found in it and for defining their relationships with the context. In other words, it is important to understand whether the objects are found in their primary deposition and whether they can be considered in their primary-usage context.

This approach to considering texts in contexts differs from the methods practiced so far, and it is certainly more complex. Yet, the stratigraphic unit context and the dynamics of its formation are the starting point for a correct interpretation of the text

18 Archaeological reports often refer to buildings and their content while analyzing mainly the floor level and without taking into consideration the original volume of the building. In these cases, the spatial analysis of the objects distribution is limited to a small part of the original living space and is thus often untenable, cf. Margueron/Gransard Desmond 2012, 397-410. 
in context and vice versa. ${ }^{19}$ This is feasible for the excavations with detailed documentation of the stratigraphy.

I must say that interpreting the stratigraphy is not as easy as it may appear and that, alas, the ideal excavation with perfect documentation does not exist, because the work is done by people and people can make various mistakes. An archaeological excavation is not an easy undertaking and the archaeologist is not a technician who applies mechanical rules in the action and in recording data. ${ }^{20} \mathrm{~A}$ proper archaeologist is more than a technician as well as a papyrologist is more than a translator. These basic and banal considerations are worth repeating to avoid potential misunderstandings in both fields. Interpretation is a key word for both disciplines, and in archaeology it comes with a good eye to identify stratigraphic units in the field. Mistakes in definition and identification of stratigraphic units are always possible, but proper documentation can usually help catch and resolve errors during the study process with all the data available and through a constant exchange of knowledge and opinions with specialists, including papyrologists. Such collaborative work leads to a better understanding of the stratigraphy and consequently of the general context, of the dynamics and chronology of construction, renovation, abandonment and post-abandonment phases of the excavated buildings. ${ }^{21}$ The role played by the artefacts in this process of comprehension is important inasmuch as they are related to the formation of the layers. In this respect, the texts can gain extra information from the archaeological context, and vice versa.

Among the most critical factors for the correct evaluation and interpretation of the contexts is the identification of the occurred negative actions, often not clearly recognizable, and of the post-abandonment events, which may have altered at different times the original state of things. ${ }^{22}$ The continuous transformation of buildings and of their contents in time must always be present in the mind of the scholar. Rarely do we find situations where settlements ceased to live suddenly and were then sealed, as in the case of Herculaneum and Pompeii. And even if the last stage of habitation was "frozen" and therefore offers us the possibility of a complete contextual study of

19 Nevett 2011, 24 suggests a similar approach: “[...] archaeology can be used more effectively by analyzing it independently of the texts, rather than as a supplement to try to fill in details which the documentary sources omit."

20 Very interesting for the methodology and the results is Stephan 2010; however, the author assumed that the data set produced by the University of Michigan Excavation in Karanis is reliable in attributing papyri to levels. There is no discussion about reliability of the data set and about the fact that the pattern distribution resulting from composed GIS is mainly accidental because of the numerous variable that cause the disappearance or the conservation of the papyri. Nevertheless, the general overview of the distribution of the papyri in a settlement is an interesting perspective, even if the relativity and the accidental nature of the data preservation must never be forgotten.

21 The members of the two excavation teams I have the opportunity to direct, in Soknopaiou Nesos/ Dime and Trimithis/Amheida work in strict synergy. For the so-called reflexive method, see Hodder 2000. 22 See at least Cameron/Tomka 1993. 
buildings, people and objects, previous phases of habitation must be recognized and their interaction in the sequence/evolution of the buildings/settlement evaluated. The very life of the building and of the people who lived there entails continuous changessometimes irrelevant, other times important-even within a limited time frame.

The dynamism of a residential context, in which ostraca and papyri can be found, is very high in terms of time and space. Materials and objects found inside a room did not necessarily belong to the life of that building, and even if they did, they may or may not have been original belongings of the inhabitants: they might have been collected to be reused, for example, and then left behind. Among possible reasons for an object to be in a certain context is the reuse of materials, a very common practice in Antiquity, much more frequent and extensive than commonly thought.

\section{Practical Approach: A Case Study}

As examples, I will refer to my own experience in excavating Greco-Roman settlements located in the western desert of Egypt, like Soknopaiou Nesos/Dime in the Fayum and Trimithis in Dakhla Oasis, contexts in which ostraca and papyri are preserved. The fairly good state of preservation of the two settlements is due to their original and current position in the desert; sand is the basic matrix of the stratigraphy together with mud used to made bricks and buildings, as well as floors. One of the main character of these settlements is their long life, from pre-Ptolemaic to Late Roman periods, which has led to the formation of artificial hills (kiman) formed by sequences of superimposed layers of anthropic and natural deposits, where positive actions acted together with negative ones, meaning, for example, construction and demolition of buildings or production and reuse of materials. Beside actions purposefully carried out by people living there in the past, we have to take into consideration natural phenomena as well as recent anthropic tampering, which all play a role in the formation of the current state of an archaeological site. In this kind of environment, natural phenomena that could affect a settlement during its habitation phase as well as after its abandonment consist mainly of sand accumulation and erosion, both caused by the desert winds, but there also occur earthquakes, subsidence and rains. The post-abandonment period up to present day has been about fifteen centuries, during which changes in natural, social and economic environment occurred and affected directly or indirectly the preservation of the sites. ${ }^{23}$ The dynamics that form the current state of the archaeological sites are complex and deserve much attention, because the correct interpretation of the archaeological remains can depend on a general understanding of these dynamics. In this kind of environment identification, interpretation and understanding of changes can be a challenge.

23 See Davoli 2015, 87-112. 


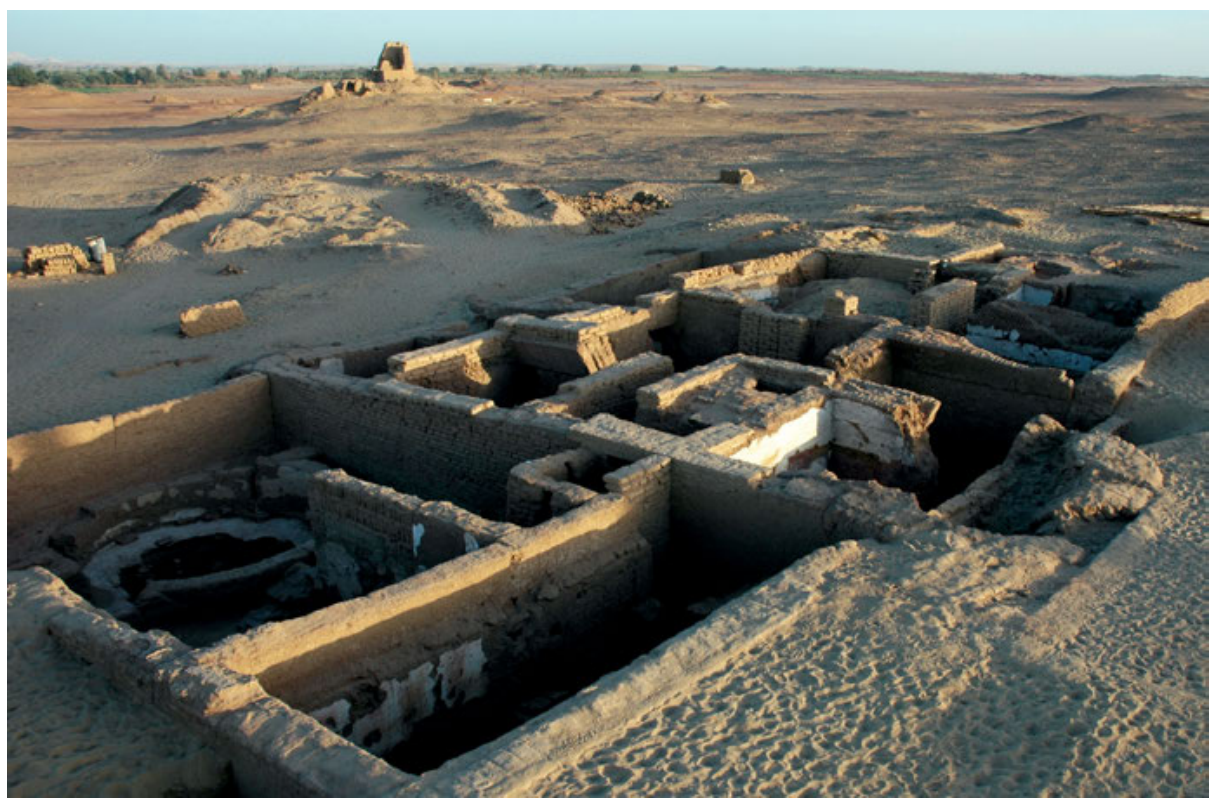

Fig. 2: Amheida area 2.1. The house of Serenos (B1).

The excavation of the fourth-century house of Serenos and its surroundings at Trimithis in the Dakhla Oasis has been, in my opinion, a successful example of the contextualization of texts according to the "alternative method" I described above. The archaeological Mission of New York University, directed by Roger Bagnall and myself as field director, found many Greek texts on more than one thousand ostraca and on walls (but no papyri) in the areas excavated so far.

The house of Serenos is completely preserved at ground floor and up to about $2.5 \mathrm{~m}$ in height (Fig. 2). The destruction of the upper part was due to erosion because it was exposed and not protected by the desert sand, which invaded the interior of the ground floor shortly after the house was abandoned. Mixed into the 2.5 meters of windblown sand were the collapses of walls and ceilings (Figs. 3 and 4). We could ascertain that the filling of the rooms was not recently disturbed, except for a few centimeters on top surface and for parts of room 1, where a rich painted decoration was repeatedly exposed. The majority of the stratigraphic units excavated were thus reliable: ostraca, other potsherds, and small objects were recovered at different elevations within the rooms and basically in four different kinds of deposits: single objects scattered in windblown sand, groups of objects mixed with collapsed walls or ceilings, scattered objects in the dust covering the floor, and objects below the floors. The subsequent question was whether we could consider all the ostraca found in the filling of one room as part of the life of that room. In most cases we could ascertain that this was not the case. The identification and separate excavation of each stratigraphic unit, mainly identified by materials and position, gave us the possibility to keep apart 

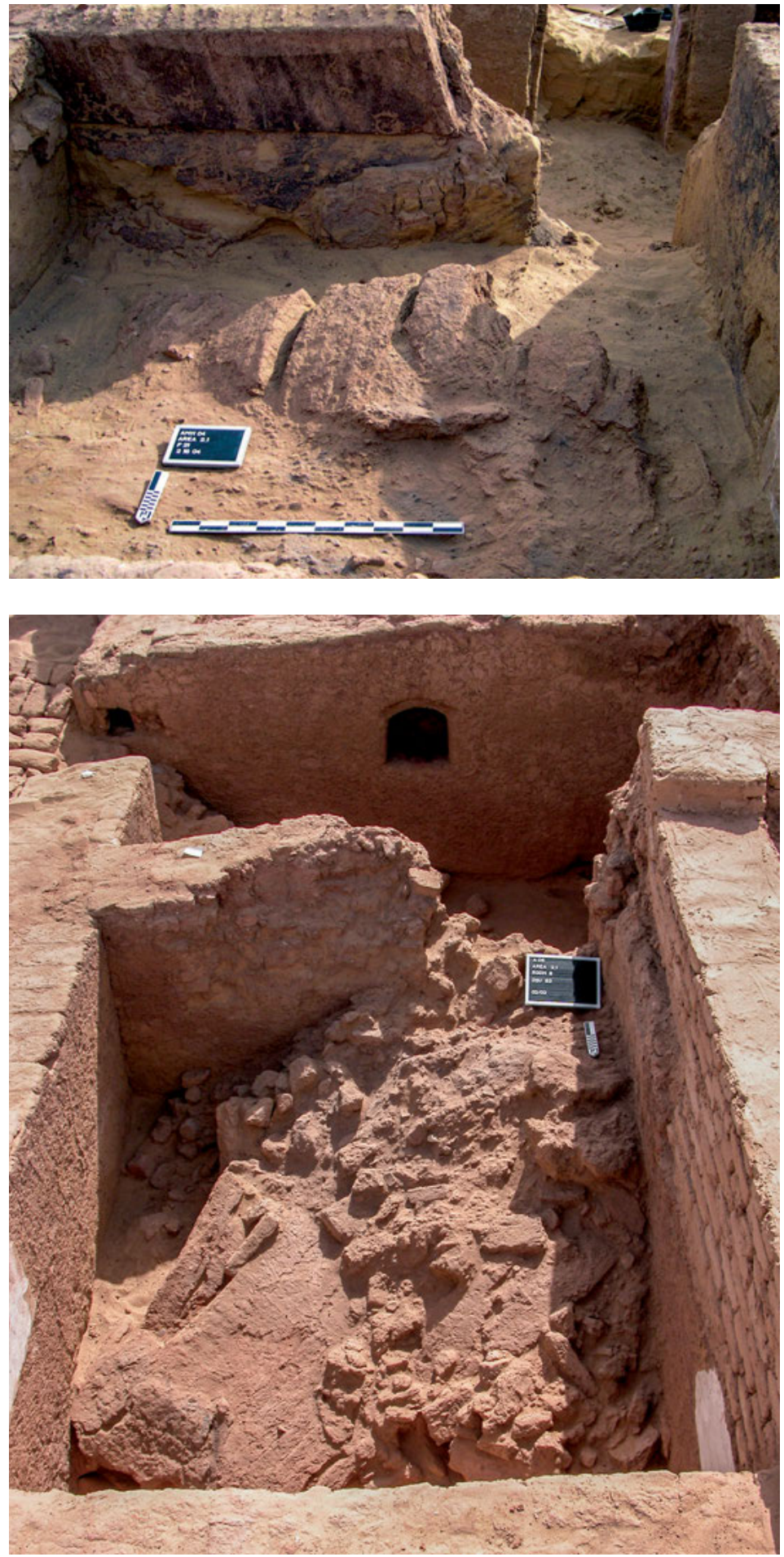

Fig. 3:

Amheida: filling of room 4 in Serenos's house: windblown sand and collapsed ceiling.
Fig. 4:

Amheida: filling of room 8 in Serenos's house. The collapse of the ceiling. 


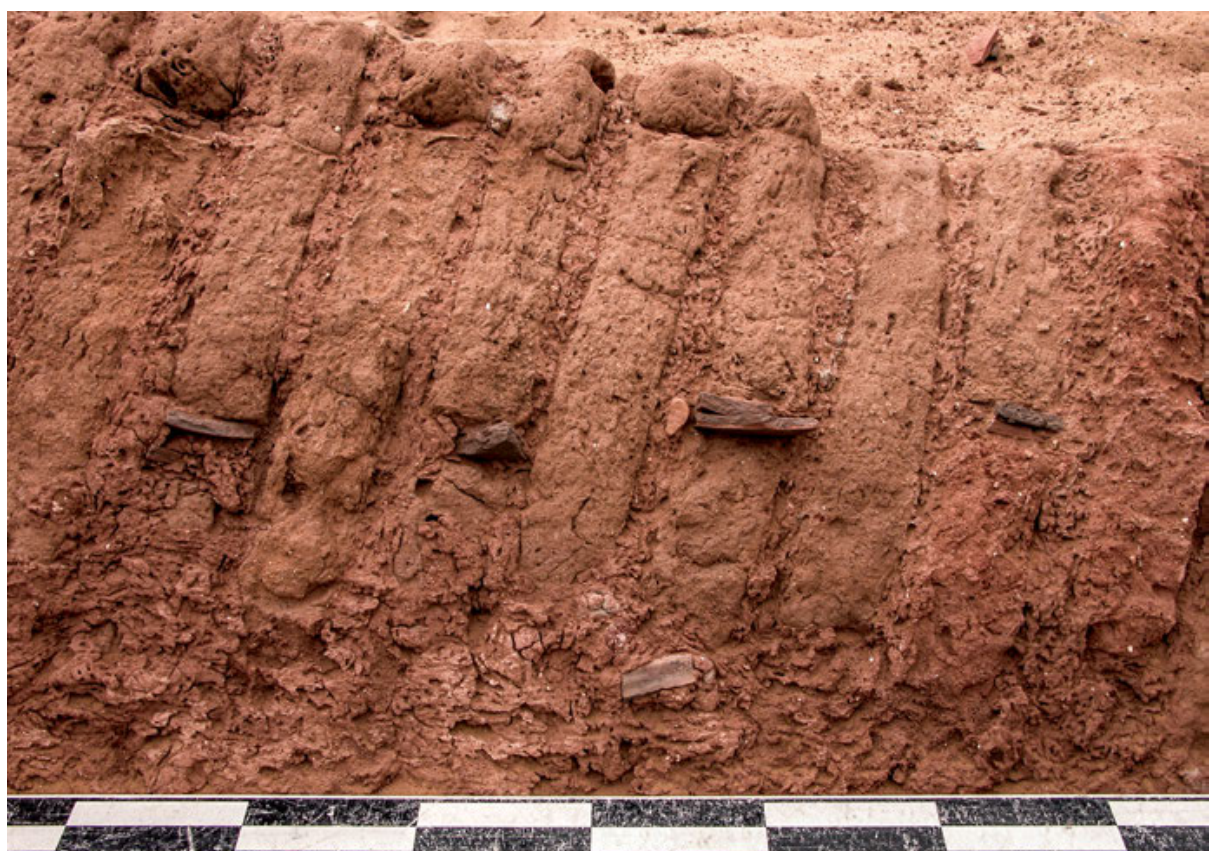

Fig. 5: Amheida: detail of the vault of room 14 in Serenos's house with chinking sherds.

the objects found in them and to study the dynamics of formation of the deposits. The study of all materials forming the stratigraphic unit is necessary to determine its nature and possibly the date of its formation, while the study of single objects gives us better clues about the overall significance of the context. Thus, objects found mixed in a collapsed roof can be explained as part of the original upper story, whether a terraced roof or another room. However, this is not always the case with potsherds, as we have seen at Trimithis, where they are frequently used in mud brick masonry as chinking sherds or filling (Fig. 5). Accordingly, we have at least two explanations for the original provenance of the objects found in a collapse: they could have been objects used in the house but in a different room or area, or they were waste reused as building material. I will refer to these objects as "cluster type 1".

Single objects floating in windblown sand filling are probably intrusions and it is impossible to know how, why, and when they ended up there. Their connection with the house or the room is therefore uncertain ("cluster type 2").

On the floor, we would expect to find the furniture of the room or whatever was left of it. The house of Serenos must have been richly furnished judging from a group of bronze lamps and vessels hidden in a pit in the floor of room 4 and the expensive painted wall decoration in four rooms, but apart from this, nothing relevant has been found. At a first glance, it looked like the abandonment was a slow process during which the family transferred all they could. However, the presence of that bronze treasure and of a couple of possible coin hoards hidden in rooms 4 and 14 suggests that 


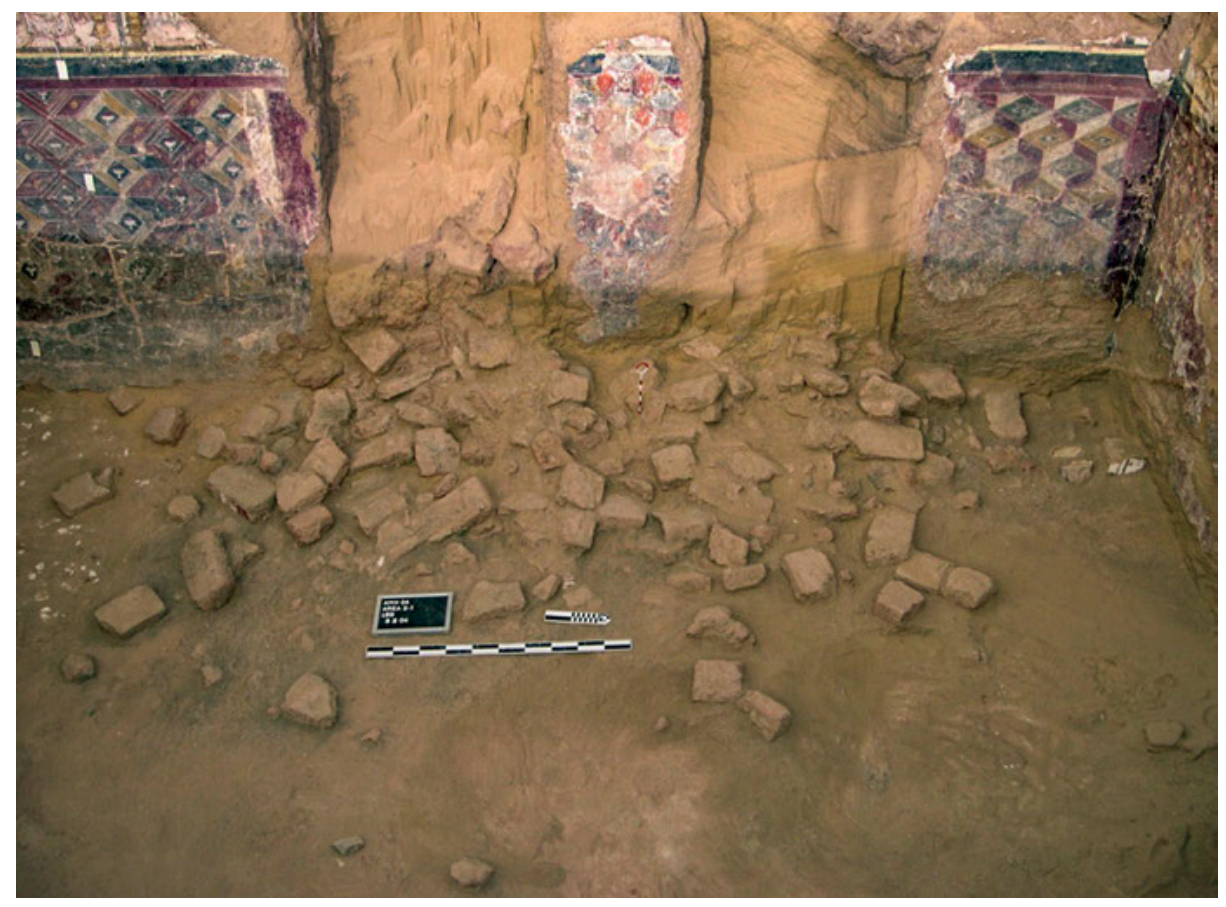

Fig. 6: Amheida: collapse of a wall on the floor of room 1 in Serenos's house caused by the robbery of the wooden lintels of the two doors.

the family intended or hoped to return. ${ }^{24}$ One would expect that in this case at least some pieces of furniture should have been left in situ, too. However, shortly after the abandonment, the house must have been entered by people who probably ransacked the furniture and removed all the wood elements, like the lintels and jambs of the doors and from the flat roofs, which caused at the same time abrupt collapses and the destabilization of walls and of the other ceilings (Fig. 6). As a result, what we have found on the floor are the ostraca and objects collapsed from the top of the room (with the same distinction as we have seen for "cluster 1") mixed with de facto refuse left behind on the floor by the family and by the robbers (Fig. 7). ${ }^{25}$ All these refuses are in their primary deposition, but among them only a few can be ascribed to the last phase of occupancy of Serenos's family and thus considered as of primary use (I will refer to this group of objects as “cluster type 3"). Again, it was not simply the position within

24 The hypothesis that the coins found in these two rooms belonged to hoards is supported by the fact that they were numerous and scattered at floor level. In both cases the mud floors were not preserved and they turned into powder because of the collapse of the ceilings. The collapses may have crashed the pots or containers where the coins were collected, presumably hidden in pits below the mud floors.

25 On definition of de facto refuse, cf. Schiffer 1987, 89-96. 


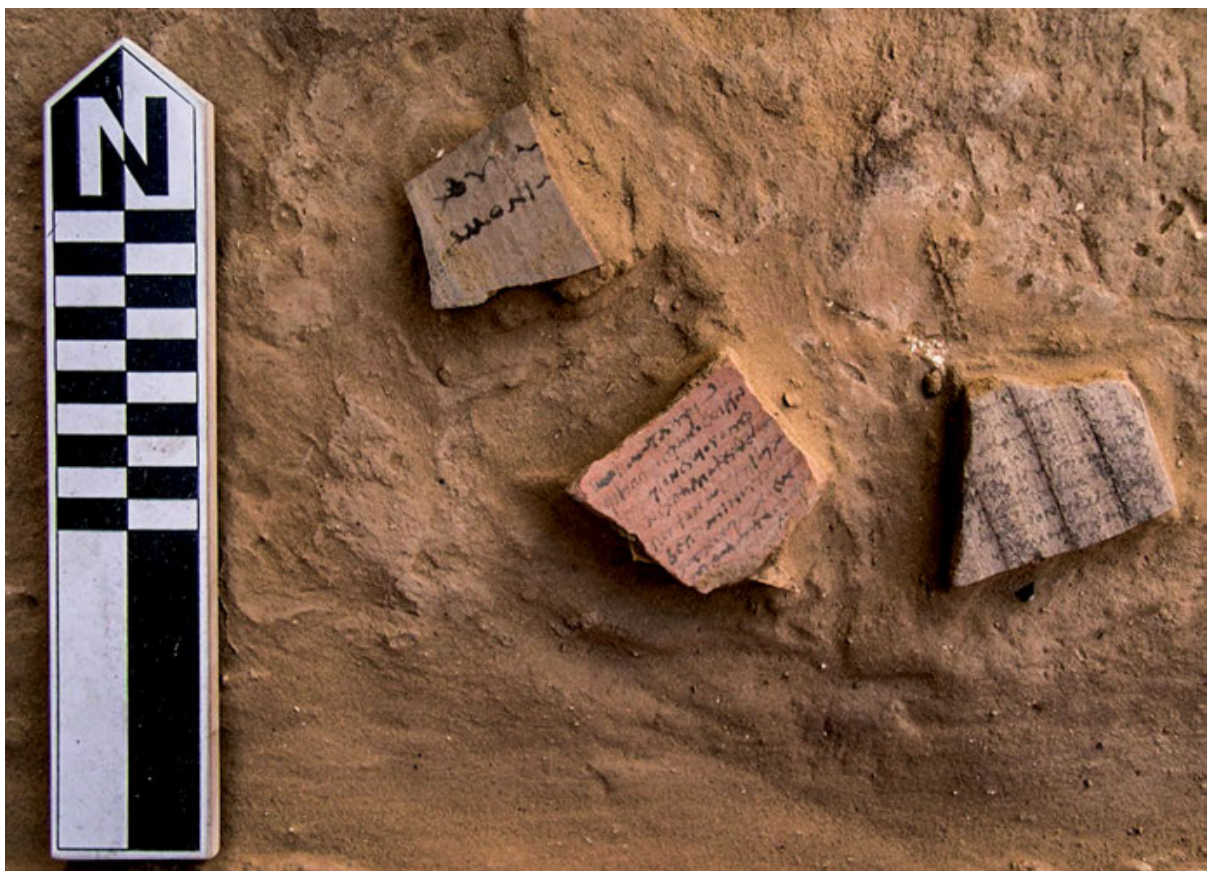

Fig. 7: Amheida: ostraca on the floor in room 2 in Serenos's house.

the room that implied a connection between the objects and the original family living there. Rather, to determine whether there was a connection, we needed first to analyze and interpret the dynamics of the formation processes of every stratigraphic unit and to identify, when possible, which materials were in their context of primary use.

On the basis of several ostraca found on the floor in the house and identified as de facto refuse, the team's papyrologists were able to attribute the house to Serenos and his family. ${ }^{26}$ These ostraca provide a series of names of people belonging to the same family and of related persons, whose activities span the period from about 330 to 370 CE. Serenos, a member of the city council, is the central figure in these texts. ${ }^{27}$ Business letters and delivery orders, some of which were written and signed by Serenos himself, reveal a circle of individuals engaged in estate activities centered around him. ${ }^{28}$ Most of these names appear also on ostraca found in a small dump accumulated just outside the house, in a narrow alley (room 43), and composed of domestic waste. The origin of this waste was thus recognized as the house of Serenos. Other ostraca identified through their names as related to the family were found in ceiling collapses ("cluster 1") and attributed to the upper story of the house.

26 Bagnall/Ruffini 2012; Ast/Bagnall 2016.

27 Bagnall et al. 2015, 87.

28 Ast/Davoli 2016, 1458. 


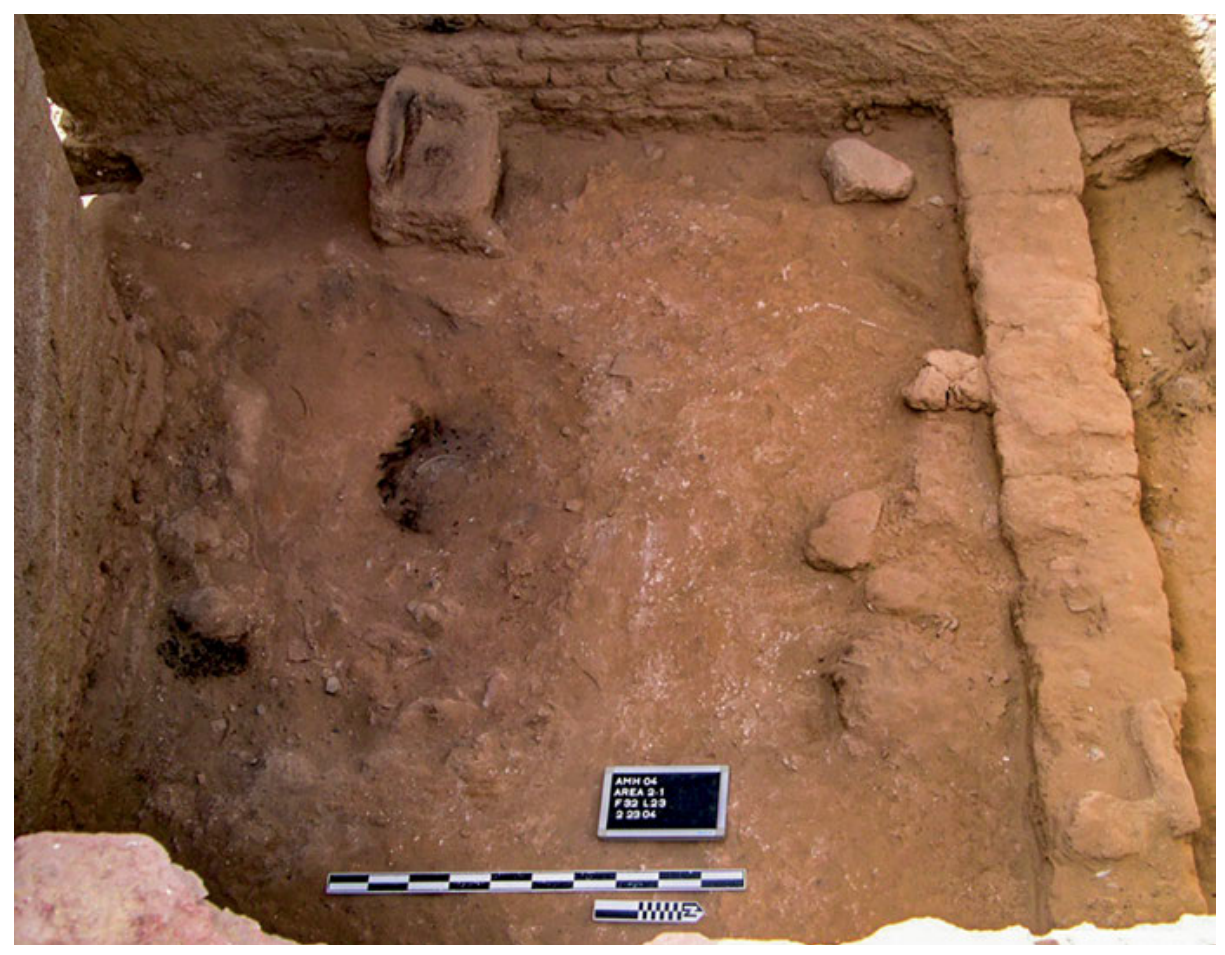

Fig. 8: Amheida: the powdered floor in room 4 in Serenos's house.

Ostraca and objects found at floor level in room 4, of clearly mixed dates, suddenly disrupted our puzzle of the evidence (Fig. 8). In a closer examination of the room and its filling, we observed that the floor, made of common compacted mud, disintegrated under the weight of the collapse of the ceiling and became powder. As a consequence, the materials on the floor were comprised of those originally imbedded in the floor and of those below it, which belonged to the filling of the foundation of the room. Since they all came to be mixed together, they were collected by the archaeologists as one stratigraphic unit. In this case, we could go back to the original deposits of the objects thanks to a very accurate documentation of the elevation and position of single ostraca and coins and of most of the other diagnostic pieces, which allowed us to identify the materials originally buried below floor. The objects imbedded in the foundation filling ("cluster type 4"), which had been sealed by the mud floor, were not part of room 4 habitation phases even though they were found there. This was the first time we encountered a dump underlying this area and we continued to find the same dump below the other floors of the house, as well as below the floor in the streets (Fig.9). In the latter area we found hundreds of ostraca predating the foundation of Serenos's house, which had nothing to do with this family. Several years of excavations and of studying the stratigraphy, with its features and objects, in a constant exchange of information with the colleagues of the team allowed us to reach a quite 


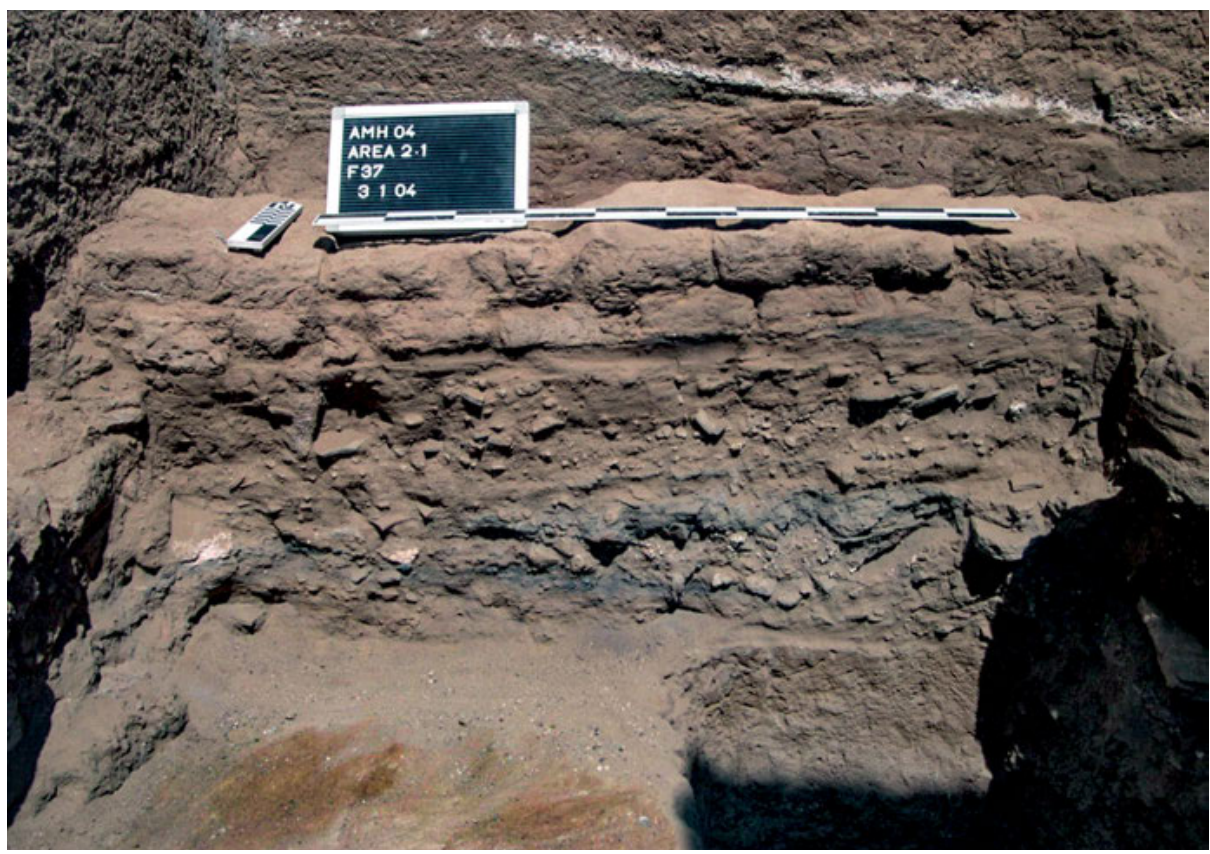

Fig. 9: Amheida: waste filling the foundations below floor in room 4 in Serenos's house.

clear view of the formation and reuse of this dump..$^{29}$ The stratigraphic excavation of the dump and the subsequent study of the materials found there allowed us to understand its peculiar formation. It turned out that it was formed not where it was found, but was spread out on purpose over the area. Pottery, objects, and ostraca found in the different layers of the dump were in fact mixed and are not chronologically stratified, with twin ostraca found in different places and deposits. ${ }^{30}$ We came to the conclusion that a dump (or more than one) was used to flatten the area where Serenos's house was built. The materials found in it date mainly from the second to the end of the third century CE, with a few pre-Dynastic and pre-Roman items. In this case, the connection between the texts and their find contexts is not significant at all, as they come from artificially displaced waste. Nonetheless, significant data were recovered concerning the original use of a certain type of small ostraca with short texts: for the first time, we found some of them still embedded in the mud stoppers sealing jars and realized that they were tags (Fig.10). The purpose and meaning of these short texts became clear because of the recovery of their primary context of use: the mud stopper. They supply information on the origin of the content of the jar through the mention of a plot of

29 Ast/Davoli 2016, 1447-1471.

30 A good example of twin ostraca (ostraca with the same shape and text) are inv. 11699 from below room 4 and inv. 14089 from below Street 2 (= 0.Trim. 1.123 and 0.Trim. 2.599). On methods of dump interpretations, see at least Sosna/Brunclíková 2017. 


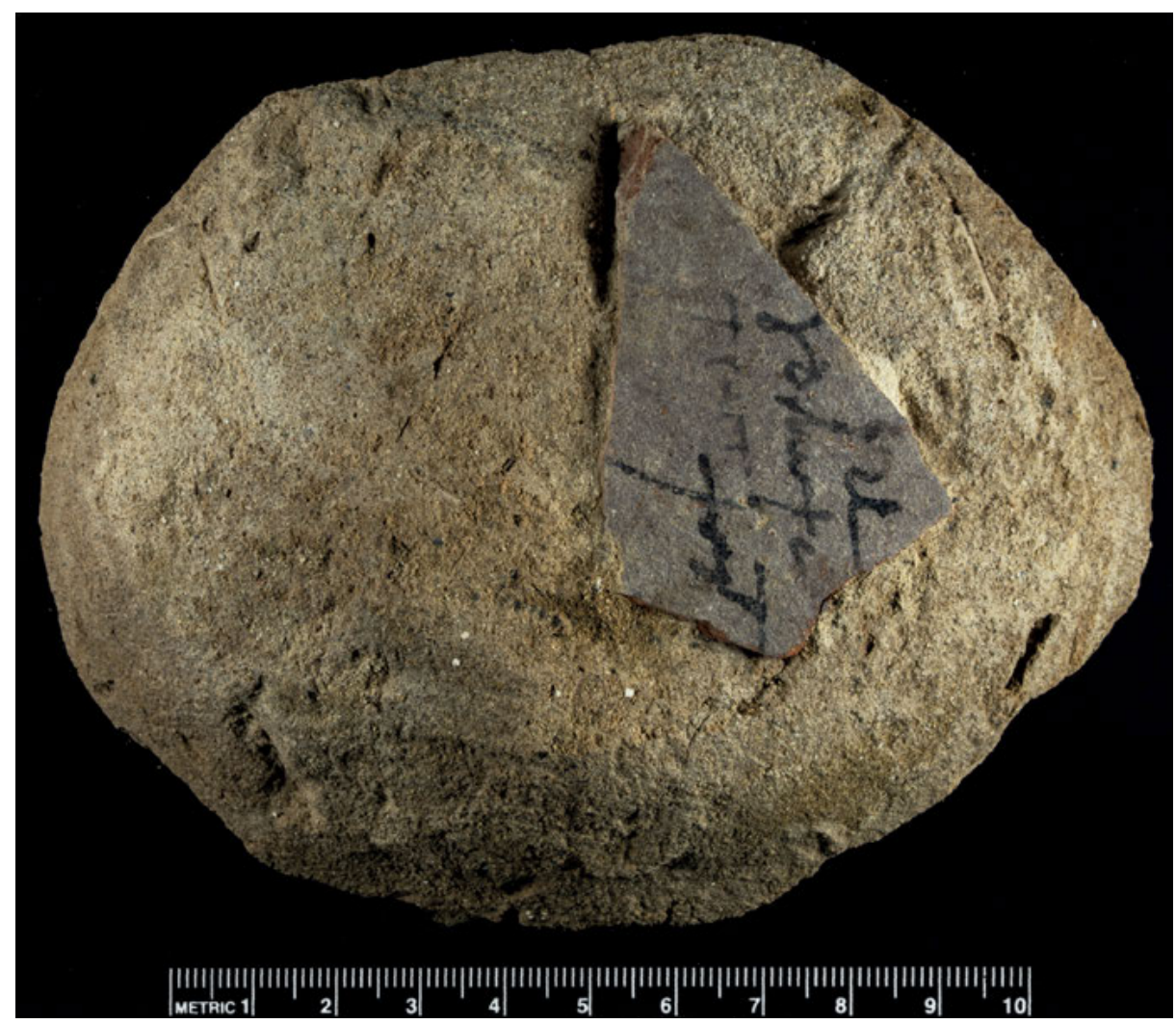

Fig. 10: Amheida: tag-ostracon on a mud stopper.

land named after the well, as well as the name of the tenant. The texts close with the regnal year of production. ${ }^{31}$

These jar-tags are common finds in Trimithis in the excavated areas, and their use is attested in the third and fourth century CE. Their texts produced a good deal of information about economic activities and personal names, while the study of the pottery supports by Clementina Caputo opened new perspectives on the way these tags were produced..$^{32}$ Moreover, their connection with the stratigraphy and contexts allowed us to define better their chronology and expand our knowledge of different networks of people. The personal names mentioned on them, for example, can be assigned to two groups, one with traditional Egyptian names and the other comprised of Greek, Roman and Christian names. The two groups are also chronologically distinct as belonging to pre- and post-Diocletian (284-305) periods. $^{33}$

31 Ast/Davoli 2016, 1459.

32 Caputo 2016, 62-88.

33 Bagnall 2015, 116-118. 
The texts of the ostraca studied according to their archaeological contexts are published in two volumes in the Amheida series publications, ${ }^{34}$ and the impact of the stratigraphic study on the comprehension of the texts and vice versa is immediately evident. Although in our excavations we never use ostraca and coins as chronological markers of stratigraphic units, in some cases we were able to refine the contexts' date to specific years thanks to ostraca and coins, a precision that would not be possible on solely the basis of typology of pottery and objects. Thanks to our reliable contexts, the richness of data recovered in different excavated areas, the fairly precise chronology of the various occupation phases, our ceramologists were able to establish good chronologies for the use and production of several types of vessels. ${ }^{35}$ This important contribution was made possible by the precision in dating the stratigraphy, which is based on its careful multidisciplinary study and on analysis of texts in their archaeological context.

The case study presented here, as far as archaeological situation is concerned, is of average complexity. The results of the multidisciplinary study of the evidence collected according to the stratigraphic unit method allowed us to distinguish among events that occurred at different times in the past and to assign the texts, ostraca in this case, to their proper phase of use rather than to the building or the place where they were found. As we have seen, ostraca from clusters 1 to 4 have different provenance, dates and use even though they were found in the same room or building. Furthermore, we learned that ostraca, like other potsherds, may have had many lives as a durable material well suited to be reused several times and for different purposes. For this reason, ostraca can be found in contexts and deposits of a later date than those of their primary use and thus we must be very cautious in their evaluation within the find contexts. Their identification and dating independently from those of the archaeological context is thus essential to avoid misinterpretations. However, the possibility to study the archaeological context in its entirety, that means in its stratigraphic sequence and with the data coming from all the materials and objects found in it, can explain the "function" of the ostraca within the context.

\section{Conclusions}

Beside deficiency of documentation of earlier excavations, there seem to have been two main problems in the past studies concerned with re-contextualization of papyri and ostraca that prevented satisfactory results. Firstly, attempts to study texts within their findspots tend to pay little to no attention to the formation processes that brought them to those spots. Secondly, such studies are usually carried out by specialists of

34 Bagnall/Ruffini 2012; Ast/Bagnall 2016.

35 Bagnall et al. 2017, 195-211; Caputo/Marchand/Soto 2017, 1011-1026. 
a single discipline, such as papyrology, even when a need for an interdisciplinary collaboration is acknowledged. While a good knowledge of archaeological theories about data interpretation is certainly a good starting point, archaeological skills and field experience, in particular of the kind and nature of the archaeological remains we are dealing with, is crucial for a reliable critical approach to the data and to the records produced by the archaeologists. A multidisciplinary approach in the true meaning of the term, which entails a collaboration of different specialists in the field, in which archaeologists are no less important than papyrologists or historians, ${ }^{36}$ is surely the best way to make sense of our data. I am well aware that this is not an easy task, especially when we have to deal with earlier excavations, yet it can be aimed for when circumstances allow it. The integrated multidisciplinary approach adopted by the Amheida team ${ }^{37}$ has produced highly satisfactory results. There, papyrologists, historians, ceramologists, and archaeologists, all with their own skills, were essential in building the complex picture and none of them would have reached the same result without the others. Studying the texts within their contexts and studying the archaeological contexts with texts in them are a very complex matter that no single specialist can afford, as already noted some years ago by the late Traianos Gagos and his collaborators. ${ }^{38}$

\section{Bibliography}

Ast, Rodney/Bagnall, Roger S. (2016), Amheida III. Ostraka from Trimithis, Volume 2: Texts from the 2008-2013 Seasons, New York.

Ast, Rodney/Davoli, Paola (2016), “Ostraka and Stratigraphy at Amheida (Dakhla Oasis, Egypt): a Methodological Issue", in: Proceedings of the 27th International Congress of Papyrology, Warsaw, 29 July-3 August 2013 (The Journal of Juristic Papyrology Supplements 28), 1447-1471.

Bagnall, Roger S. (2015), “Onomastics”, in: Roger S. Bagnall, Nicola Aravecchia, Raffaela Cribiore, Paola Davoli, Olaf E. Kaper and Susanna McFadden (eds.), An Oasis City, New York, 116-118.

Bagnall, Roger S. (2016), “Materializing Ancient Documents”, in: Daedalus 145 (2), 79-87.

Bagnall, Roger S./Aravecchia, Nicola/Cribiore, Raffaella/Davoli, Paola/Kaper, Olaf E./McFadden, Susanna (2015), An Oasis City, New York.

Bagnall, Roger S./Caputo, Clementina/Casagrande-Kim, Roberta/Soto, Irene (2017), “New Evidence from Ostraka for the Dating of 4th-century CE Ceramic Assemblages", in: Bulletin de la liaison de la Céramique Egyptienne 27, 195-211.

Bagnall, Roger S./Ruffini, Giovanni R. (2012), Amheida I. Ostraka from Trimithis, Volume 1: Texts from the 2004-2007 Seasons, New York.

Bowen, Gillian E. (2015), "The Environment Within: the Archaeological Context of the Texts from House 3 at Kellis in Egypt's Dakhleh Oasis”, in: Andrea A. Di Castro and Colin A. Hope (eds.),

36 Multidisciplinary approach is traditionally difficult within humanities, see Pavel 2017, 71.

37 See also Bagnall et al. 2017.

38 Gagos/Gates/Wilburn 2005, 186. 
Housing and Habitat in the Ancient Mediterranean, Cultural and Environmental Responses, Leuven/Paris/Bristol, 231-241.

Cameron, Catherine M./Tomka, Steve A. (eds.) (1993), Abandonment of Settlements and Regions. Ethnoarchaeological and Archaeological Approaches, Cambridge.

Caputo, Clementina (2016), “Ceramic Fabrics and Shapes”, in: Rodney Ast and Roger S. Bagnall, Amheida III. Ostraka from Trimithis, Volume 2: Texts from the 2008-2013 Seasons, New York, 62-88.

Caputo, Clementina (2018), "Gli ostraka e l'importanza del supporto scrittorio: evoluzione delle metodologie di studio”, in: Paola Davoli and Natascia Pellé (eds.), Polymatheia. Studi classici offerti a Mario Capasso, Lecce, 677-701.

Caputo, Clementina (2019), "Looking at the Material: One Hundred Years of Studying Ostraca from Egypt”, in: Cornelia Ritter-Schmalz and Raphael Schwitter (eds.), Antike Texte und ihre Materialität: Alltägliche Präsenz, mediale Semantik, literarische Reflexion (Materiale Textkulturen 27), Berlin/Boston, 93-117.

Caputo, Clementina/Cowey, James M. S. (2018), "Ceramic Supports and Their Relation to Texts in Two Groups of Ostraca from the Fayum", in: Francisca A. J. Hoogendijk and Steffie van Gompel (eds.), The Materiality of Texts from Ancient Egypt: New Approaches to the Study of Textual Material from the Early Pharaonic to the Late Antique Period (Papyrologica Lugduno-Batava 35), Leiden/Boston, 62-75.

Caputo, Clementina/Marchand, Julie/Soto, Irene (2017), "Pottery from the 4th-century house of Serenos in Trimithis/Amheida (Dakhla Oasis)", in: Delphine Dixneuf (ed.), LRCW 5. Late Roman coarse wares, cooking wares and amphorae in the Mediterranean (Études Alexandrines 43/2), Alexandria, 1011-1026.

Carandini, Andrea (2017), La forza del contesto, Bari.

Claytor, W. Graham (2014), “The Threshold Papyri from Karanis”, in: Terry G. Wilfong (ed.), Karanis Revealed, Ann Arbor, 161-164.

Cuvigny, Hélène (2009), "The Finds of Papyri: the Archaeology of Papyrology”, in: Roger S. Bagnall (ed.), The Oxford Handbook of Papyrology, Oxford, 30-58.

Davoli, Paola (2001), Archeologia e Papyri. Gli Album del Centro di Studi Papirologici dell'Università degli Studi di Lecce 2, Napoli.

Davoli, Paola (2015), "Papyri, Archaeology, and Modern History: A Contextual Study of the Beginnings of Papyrology and Egyptology", in: Bulletin of the American Society of Papyrologists 52, 87-112.

Faivre, Xavier (2015), “Inventaires des maisons”, in: Cécile Michel (ed.), De la maison à la ville dans l'Orient ancien: la maison et son mobilier (Archéologies et Sciences de l'Antiquité, Cahiers de Thèmes Transversaux ArScAn XII), 293-309.

Gagos, Traianos/Gates, Jennifer E./Wilburn, Andrew (2005), "Material Culture and Texts of GraecoRoman Egypt: Creating Context, Debating Meaning", in: Bulletin of the American Society of Papyrologists 42, 171-188.

Hodder, Ian (ed.) (2000), Towards reflexive method in archaeology: the example of Çatalhöyük, Ankara.

Husselman, Elinor M. (1971), Papyri from Karanis, 3rd series (Michigan Papyri IX), Ann Arbor. Landvatter, Thomas (2016), "Archaeological and Papyrological Inquiry at Karanis: Problems and Potentialities", in: Proceedings of the 27th International Congress of Papyrology Warsaw, 29 July-3 August 2013, Warsaw, 1493-1518.

Margueron, Jean-Claude/Gransard Desmond, Jean-Olivier (2012), “From Plan to Volume: the Need for Archaeological Analysis in 3D Modeling”, in: Archeologia e Calcolatori, Suppl. 3, 397-410.

Minnen, Peter van (1994), "House-to-House Enquiries. An Interdisciplinary Approach to Roman Karanis", in Zeitschrift für Papyrologie und Epigraphik 100, 227-251. 
Moreland, John (2006), “Archaeology and Texts: Subservience or Enlightenment”, in: Annual Review of Anthropology 35, 135-151.

Nevett, Lisa (2011), "Family and Household, Ancient History and Archaeology: A Case Study from Roman Egypt”, in: Beryl Rawson (ed.), A Companion to Families in the Greek and Roman World, Oxford, 15-31.

Pavel, Catalin (2017), "Visual Models in Archaeology and Harmonization of Archaeological and Literary Data", in: Archaeology and Text 1, 67-94.

Pernigotti, Sergio/Capasso, Mario (eds.) (1996-1999) and (2000-2003), Bakchias III-IX, Pisa and Imola.

Rathje, William L./Shanks, Michael/Witmore, Christopher (eds.) (2013), Archaeology in the making. Conversations through a discipline, New York/London.

Schiffer, Michael B. (1987), Formation Processes of the Archaeological Record, Salt Lake City.

Sosna, Daniel/Brunclíková, Lenka (eds.) (2017), Archaeologies of Waste. Encounters with the Unwanted, Oxford.

Stephan, Robert P. (2010), “Texts and Artifacts: A Spatial Analysis of Papyri at Karanis”, in: Past Imperfect 16, 92-131, DOI: https://doi.org/10.21971/P75017.

Stephan, Robert P./Verhoogt, Arthur (2005), “Text and Context in the Archive of Tiberianus (Karanis, Egypt; 2nd Century AD)", in: Bulletin of the American Society of Papyrologists 42, 189-201.

Wilburn, Andrew T./Cook, R. James/Gates-Foster, Jennifer (2014), “The Karanis Housing Project: a New Approach to an Old Excavation”, in: Terry G. Wilfong (ed.), Karanis Revealed, Ann Arbor, 157-160.

Wilfong, Terry G. (1990), “The Archive of a Family of Moneylenders from Jême”, in: Bulletin of the American Society of Papyrologists 27, 169-181.

\section{Photo Credits}

Fig.1-10: @ Amheida Project. 
